\title{
Politics of the Man Booker Prize(s): The Case of The White Tiger and Sea of Poppies
}

\author{
Satyanarayan Tiwari ${ }^{1} \&$ Ajay K Chaubey ${ }^{2}$ \\ ${ }^{1}$ Doctoral candidate at the Department of English, Dr. H S Gour Central University, Sagar. \\ ${ }^{2}$ Assistant Professor of English at the Department of Sciences \& Humanities, National \\ Institute of Technology, Uttarakhand. E-mail: kcajay79@gmail.com
}

Received May 06, 2018; Revised September 29, 2018: Accepted October 27, 2018; Published October 29, 2018.

\begin{abstract}
:
The present paper is a modest attempt to map the nuances of the politics of literary prizes and their reception in pan-global [literary] market. The discrimination in awarding the prizes is explicitly perceptible when any cultural text produced by the writers of the 'third world' is shortlisted for the prize in general, and the Man Booker in particular. It has been studied and observed that the texts which satiate the exotic lens of 'Orientalism', or carry colonial legacies, are brought to the fore to mollify the western academia. As a result, affirmative responses for a distorted picture of India portrayed by Indian/diasporic writers, has not only attracted young writers but also paved a shortcut way for them who intend to be famous overnight in the international literary firmament. Therefore, the politics of the Man Booker prize in this regard are discernible, as it not only masquerades, but also marques a writer, a celebrity.
\end{abstract}

Keywords: Third World, Orientalism, Diaspora, the Man Booker Prize, Aravind Adiga, The White Tiger, Amitav Ghosh, Sea of Poppies, etc.

I am neither mourning (nostalgically) the passing of the 'good ol'days' when authors were read and not heard or seen, nor do I resent the media-savvy Chetan Bhagats, Salman Rushdies and Arundhati Roys with their tweets and interviews on all subjects social, political and cultural. The nature of cultural production has changed across media - the cinema is a case in point - and IWE has been influenced by that change as well. (Nayar, 2014:33)

The information that twenty-first-century Postcolonial diasporic writers are 'manipulating details of India' and its people in literary texts hits the nail on the head. But Postcolonial diasporic writers cannot be accused alone for such exotic portrayal. The politics of prizes and global receptions of their literary texts, which have been a contentious issue for discussion, are also accountable for misshaping of reality. Politics of prizes and warm welcomes of unusual delineation of India are not only confined to the literary texts but also to the other cultural productions. The Occidental cinema critics have always given priority to their own film directors/producers who have distorted the reality of India by signifying her as the lands of snakecharmers, magicians, necromancers and beggars, and presented the West as superior to the East. For them, more precisely, it is the land of "an area of darkness," according to V.S. Naipaul. We have seen, of late, how Gurinder Chadha's partition movie Viceroy's House (2017) warps the information of Indian freedom struggle movement. The crux of this movie is, as Fatima Bhutto argues in her article, "I Watched this Servile Pantomime and Wept," published in the Guardian, that the freedom movement of India was not the main cause of the departure of the British from

(C) AesthetixMS 2018. This Open Access article is published under a Creative Commons Attribution Non-Commercial 4.0 International License (http://creativecommons.org/licenses/by-nc/4.0/), which permits non-commercial re-use, distribution, and reproduction in any medium, provided the original work is properly cited. For citation use the DOI. For commercial re-use, please contact editor@rupkatha.com. 
the Indian subcontinent. It was the exhaustion of World War-II that became the sole cause for the British to leave India. Bhutto impudently states, "Film is a glossy imperial version of India's traumatic partition that scandalously misrepresents the historical reality" (The Guardian, 3 March 2017). Despite such fabricated information, the movie has gained much impetus in the Western world. One can refer the Indian blockbuster movie Lagaan (2001) which can be debated here in the light of politics of prize(s). Why did Lagaan fail to win the Oscar? Why was it not even extolled much by the Western audience? The questions will prevail, even today and the best answer to this question, given by the critics, was that 'Academy did not like cricket.' 'If cricket were the national game of the United States, the result would have been different'. But Western cinema viewers appreciated Slumdog Millionaire (2009) which is candidly described by Arindam Chaudhary as "A phony poseur that has been made only to mock India for the viewing pleasure of the First World" (Others, 25 January 2009) and it had received eight prestigious awards including the Oscar. Chaudhary further elaborates his points:

There is nothing positive about the movie .... It illogically shows every negative thing about India happening in the protagonist's life... slums, open-air lavatories, riots,... blinding and maiming of kids to make them into 'better beggars', petty,.... And its winning of so many awards and nominations only goes on to prove strongly that the paradigm of cinema and recognition of films are in the hands of a few retarded imperialistic minds. (ibid)

Would it be an intrepid attempt to say that the varying parameters of personal interests played a significant role in such judgments? Alternatively asking, would it be presumptuous to ask whether movie Lagaan was rejected because it presented a superior image of the Indian team (colonized) who defeated the British team (colonizer) in cricket match which is their national game? Is it the fact that Slumdog Millionaire got recognition only because it has rightly presented the veracity of the Indian slums?

In 2008 when Aravind Adiga received the Man Booker Prize for his novel The White Tiger, academicians and critics once again questioned the 'Occidental' concept of the 'Orient' and grilled the authenticity and reliability of the jury and the process of selecting a novel for the prize. Mr. Portillo, the chairperson of 2008 Booker jury, defended his decision by asserting that he was looking for something that would "blow his socks off". This comment shook the literary world with furore. The victory of The White Tiger, which went to the extent of dividing our country India into 'Dark India' and 'India of the Light' resonated many questions on Indian diasporic writers, their subject matters, new approaches and earnest reception as well. To quote Amrit Dhillon in this context: "Adiga is the same [as Naipaul] focusing on everything that is bad and corrupt” (Telegraph, 18 Oct. 2008). Om Prakash Dwivedi and Lisa Lau made an effort to show how the Indian [diasporic] writers have represented India as dark and filthy, which captivates the shape of re-Orientalism. Keeping the critique of Dwivedi and Lau in mind, few more questions reverberate-are their (diasporic authors) way of 'remembering' home in their creative feats appropriate? On the other hand, is it their unique way of presenting 'diasporic imaginary'?

Apart from the above-mentioned factors, that jury of the Booker prize deliberately preferred The White Tiger as winner, there prevails a substantial reason, considered by the critics and readers, was rejection of a more substantial novel Sea of Poppies (2008) by Amitav Ghosh which ransacked the presence of the resistance in British colonialism in its various forms and left no stone unturned to present the palimpsest British colonial subjugation. It displays how the nexus of the colonialism affected the socio-economic injustice in the Indian subcontinent during imperial rule. Jury's final decision on The White Tiger raises agitation in academic field because it 
was at the cost of the extinction of Sea of Poppies. A novel that exposed the atrocities of colonial period did not suit the committee. Therefore, they killed two birds with one stone: mocked India by giving prize to Adiga and covered up colonial reality by rejecting Ghosh. Thus, the present paper aims at analysing the desirability of one novel over the other. The objective of this paper is to unfold the uncharted possibilities which are responsible to make Sea of Poppies less insignificant for the prize than that of The White Tiger. Concurrently, we also attempt to dissect and underscore the issues explored in The White Tiger which have attracted the Jury as well as the pan-global academia.

The present essay is divided into five sections. The first section deals with the themes and techniques pragmatised in the twenty-first century selected Indian English novels in general, and Booker winning novel in particular, while the second segment offers a cursory glance on the Booker winning novels and its global reception. The third and fourth sections encompass a critical evaluation of both the novels, Sea of Poppies and The White Tiger respectively. The paper also contains comparative analyses with the previous Booker winning novels before the conclusive remarks engaged in the final section.

Politics in the arena of literary prizes is not a new-fangled issue now. We have witnessed, of late, the mêlée in pan-global academe when the Swedish Academy awarded the Noble Prize in literature to Bob Dylan, "for having created new poetic expressions within the great American song tradition", by disregarding the writers like Ngugi Wa Thiong'o and Philip Roth, and few others who have dedicated their lives to literature for sake of literature. Jonathan Barnes, one of the four critics invited by Review 31 to discuss the politics of literary prizes, opines:

Booker Prize drives publishers mad with hope, booksellers mad with greed, judges mad with power, winners mad with pride, and losers - the unsuccessful shortlisted plus every other novelist in the country - mad with envy and disappointment. Novelists had better conclude that the only sensible attitude to the Booker is to treat it as posh bingo. (Barnes)

The aforementioned critique on the Nobel Prize followed by brouhaha on it across the globe is exclusively equitable. Jonathan Derbyshire, in his article "The Politics of Literary Prize" upholds on why book award seems hard-wired to 'drive people mad' and refers Hilary Spurling, one of the judges of the 1979 Booker Prize committee, who blithely revealed that the winner Penelope Fitzgerald's novel Offshore had been "everybody's second choice" (Derbyshire). The literary prizes, especially the Booker, for Indian English writers have always been a hot cake. Nonetheless, political inclusivism, exclusively implanted by the jury in the award of the literary prizes, is often witnessed.

Unquestionably, the Indian English novel has secured a prominent position in the world literature, especially after the award of the Booker to V. S. Naipaul and Salman Rushdie in 1969 and 1981 respectively. They haven't only bequeathed a new dimension to the corpus of Indian English Literature written by Indian diasporic writers in its entirety, but also flagged off a new way of writing novels. Thus, it is evident how Renaissance in Indian English novel was observed the post-Rushdie's Midnight's Children. But the peculiar style, theme, technique, linguistic discourse and ambivalent attitude of Rushdie and Naipaul towards India revamped the hope of the Western academics to gaze at India mockingly. By doing so, they were warmly welcomed in the international literary firmament which tempted new authors and compelled other writers to maintain the new style of writing. In this context, Arpana Mahanta in "Allegories of the Indian 
Experiences: The Novels of Salman Rushdie" astutely points out, "Midnight's Children was only the latest in a whole series of fictions catering to the western desire to see India as a strange, sensual, fantastical land of 'others"' (244). The impact of Salman Rushdie is so authoritative that Indian English novel still seems to be in his clutches as if he has linguistically colonized the 'other' writers.

There is a host of writers such as Amish, Devdutt Pattanaik, Anand Neelkantan, Ashok Banker and others who incarcerated the themes of myths, religion, karma, dharma, and moksha while love, kinship, relationship in contemporary Indian society found expressions in the works of Chetan Bhagat, Ashwin Sanghi, Sudeep Nagarkar and Ravindra Singh, etc. and they, too, received accolades across the globe. There is a wide gamut of social issues, which can draw attention of global media. But the irony is that they are confined to racism, casteism, corruption, exploitation, exoticism, or cultural dilapidation in India that could occupy a place in the transnational literary scenario. Despite the fact that the authors who brought Indian English literature to the fore has been sidelined by the Indian diasporic writers and the latter one are considered to be true and authentic by the Western critics. Dwivedi and Lau point this issue: “.... if one looks at the pattern and framework of the euphoric success of post-Rushdie IWE in the global literary market, it becomes apparent that it is tendentiously marked by greater prominence being given to Indian diasporic writers than to those settled in and writing from India" (Dwivedi and Lau 2). The reason behind such assumption is that Indian diasporic writers have always exhibited a particular and strange India, twice and thrice removed from reality and their representations continually seem incompatible with the Indian English writers who live in India. Such kind of representation and exoticism by diasporic writers has given them a warm response, comeback, and popularity in the West. To quote Lau and Mendes in this context: "in contemporary Indian English Writing, it has sometimes been the case that who is speaking...matters more than what is spoken" (Lau and Mendes 28).

\section{II}

A succinct overview of the Booker Prize winning novels unveil how they have dealt with issues that are only related to India and Indians living and settled in abroad. Naipaul's novel In a Free State (1971) divulges the plights and predicaments of the Indians/Asians and the Caribbean in the United States, the United Kingdom and Canada, while Rushdie's Midnight's Children (1981) is a chronicle of a new literary era dealing with independent Indian society and political lives, which were in clamour post-1947. The most appealing themes, which have been in vogue in Indian English fiction, themes of racism and exploitation of subalterns pen-pictured in Roy's The God of Small Things (1997). The gradual eradication of a particular culture and rapid mass migration subjugated Desai's The Inheritance of Loss (2006). Adiga's The White Tiger (2008) validates the point that the jurors and the foreign readers prefer to be entertained in the novels portraying a "dark and filthy" India and blurring the bright shades of it. This postulation has become institutionalized when Michal Portillio declared boldly that it (The White Tiger) is a work, "...dealing with different aspects of India, unfamiliar perhaps to many readers. What set it apart was its originality. The feeling was that this was new territory" (The Guardian, 14 October 2008). Therefore, the dark side of India is regarded as a 'new territory', which distinguished the novel from the other contemporary novels, in general, and Sea of Poppies, in particular.

As it has been established that each Booker-winning novel 'has captured the essence of India at a particular time,' the case of Adiga's The White Tiger is different in a sense. Certain 
reasonable inferences, delineated in the novel, have already been drawn in nutshell and SectionIV would be highlighting the pros and cons of The White Tiger in detail. To us, adjudicators, in the case of Sea of Poppies, detested the reality of colonialism and bestowed priority to The White Tiger over Sea of Poppies. Our rationale in this essay, about the decision, is subjective. Nevertheless, our arguments in this paper can further be substantiated by the findings of some renowned critics who have also considered the prize in literary field as superficial and have unnerved for such type of adjudicating pronouncements. Their discountenance succours our validation in this paper. To quote Gurcharan Das, "A book should not be judged, on the basis of whether it creates a negative picture of a country. It should be seen as a works of art and judge on its literary merits" (12). Sir Simon Jenkins, former chairperson of the Booker Prize Jury, very aptly complements Das's critique:

Indian writers in English face a peculiar problem-they write about India but their readership is mostly in other countries. Because of this paradox, they create an image of India that is exotic and does not show the real India... if people create an image of India on the basis of what they see in Bollywood movies, it would be a very odd India. (12)

But the irony is that umpires of the prize giving game have arbitrarily taken 'odd India' as a real and true in Adiga's case.

III

It is clearly specified that the jury's verdict for final prizes, for a novel or a movie, has been a matter of interest and fortitude and the same action, to some extent, is repeated in the novel Sea of Poppies, when the captain of the Ibis says, ".... [Y]ou should know that on this vessel I am its sole maker. While you are on the Ibis and while she is at the sea, I am your fate, your provider, your lawgiver" (Ghosh 404). Ostensibly, these words are germane in the case of the judges who act as the captain of the ship (the jury). They acted on their own whims and fancies. The girmitiyas is to the captain what the novel is to the jury. It is speculated that the imperial conviction deliberated authenticity in 'dirt, dust and defecation' in India according to Naipaulian ideology. Therefore, the socio-political insurrection in Midnight's Children, issues of subalterns in The God of Small Things, concern of India's rigid class system in The Inheritance of Loss and murky image of India in The White Tiger received a warm reception in western academic souk.

Broadly speaking, the novel, Sea of Poppies, is about indentured labourers during colonial India. However, shifting onus to monolithic agenda would be erroneous, as this novel cannot be pinioned to solo motif. The jury members committed this mistake and stippled the novel into a linear direction. Conversely, the novel is also about, what Ghosh himself stated in an interview with Priyamvada Gopal, "...not about any one thing...there can be no doubt that colonialism was the dominant political reality of the $19^{\text {th }}$ century India. Yet, it is important to remember that it was just one aspect of that reality: people also lived and laughed and loved" (1). The discourse of Ghosh's writings has always solidified the importance of individual over nation. Sajalkumar Bhattacharya in his essay entitled "Amitav Ghosh: The Indian Architect of a Postcolonial Utopia” quotes Ghosh's claims, "History remains at the background, but a hundred individual exist living the history in their own ways. An artist aims to bring these different stories to the fore" (130). It is the case of Sea of Poppies in which Ghosh, from the different parts of the country, brings stories of individuals that provides us different perspectives. It is only the artisanship of Ghosh, which intensifies the destiny of every character leading to a ship. All the stories of individuals, 
chronicled in the novel, gradually lead to finality. Portrayal of viciousness, maltreatment, anguishes, chastisement in the novel has never been the focal chunk of the novel rather it is integrated in individual stories.

Representing women's condition in $19^{\text {th }}$ century, a story of Deeti's travails and tribulations illustrate how the then society compelled her to be a sati on the death of her husband. The reason behind being sati was not usual, which used to be during those days. There are number of reasons of her opting for satitva-it was her vulnerability, fostering of her daughter, Kabutari, coercive approach of the company's officers over farmers and farming full of insolvency, etc. Deeti narrates her adversity:

The hut's roof was urgently in need of repair, but in this age of flowers, thatch was not easy to come by: in the old day, the fields would be heavy with wheat in the winter and after the spring harvest, the straw would be used to repair the damage of the year before. But now, with the Sahibs forcing everyone to grow poppy, No one has thatch to spare. (29)

While narrating Deeti's story, Ghosh also throws light on asami contract where people were forced to sign a contract irrespective of their choices. Deeti's story is the story of affliction. Even her early years of marriage life brought her nothing but misery and feebleness. On the contrary, the most appealing and shocking story in the novel is the story of a wealthy Raja Neel Rattan Haldar, whose dynasty has been governing the zamindari of Raksauli state. It is a direct, deliberate, and arbitrary example of cruelty, inhumanity, and heartlessness in the colonial period where a king, by the trickery, not only charged on counterfeit but also transported to Mauritius for seven years as an indentured labourer. On the ship, vindictiveness of the Sahibs is hard to define: "now another hand took hold of his kurta and tore it apart so as to lay bare his underclothing...orders like, bend him over, check his arse... left Neel in astonishment" (Ghosh 290). Even we, as a reader skip to read descriptions like:

Ah Fatt was swallowing convulsively now and his fingers were trembling...They, with shaking, unstead hands he took hold of his penis and pointed it to Neel.... 'Go on then', urged the mate. 'Do it...never let yerprickoryer purse fail ye, as the cockqueans says'. Closing his eyes, Ah Fatt turned his face to the sky and squeezed out a thin trickle of urine over Neel... (Ghosh: 458)

A Raja is being treated in such a manner and gets a new identity as a 'forgerer, alipur 1838 ', what would have happened to subject. How can the west appreciate such a description where their atrocities and cruelty are exposed?

Representation of casteism and capriciousness of zamidari system finds expression in Kalua Story. Whether it was his love for Deeti or respect, his rescue of Deeti from the rituals of sati and their union is a major part of the novel. Taking this notion in mind, Ghosh has also introduced a story of divine and spiritual love between Taramony and Baboo Nob Kisan. Kisan decided to develop platonic and pious love for Taramony. He says, "[Y] ou will be my temple and I will be your priest, your worshiper, your devotee" (Ghosh162). The movement he realized that his strength is going to be powerless he begged her, "Take me with you; don't abandon me to live alone in this world. Other than you, there is nothing of value in my life... What will I do on this earth without you?" (ibid). Taramony replied Kisan's questions, "[Y]our work in this world is not yet done. You must prepare yourself-for your body will be the vessel for my return" (ibid). Kisan, 
by putting the keys of fetters in Neel's hand, completes his work in the world and feels the presence of Taramony in his eyes.

Thus, the Ibis, a giant umbrella for girmitiyas, metaphorically represent $19^{\text {th }}$ century portrait of India. It illustrates the ferocity of colonialism and its repercussions and instantaneously reveals how girmitiyas in the fires of Gehenna 'lived, laughed, and loved. 'Hence, Ghosh's Sea of Poppies deserves a special mention in the plethora of Indian novels in English for its depiction of an independent woman, Deeti, who despite the shackles of her milieu transcends the boundaries of space and even time to emerge as the paradigm of a triumphant human soul.

IV

Before we delve deep into the novel, The White Tiger, a survey of criticism produced by the critics from time to time is prerequisite to refurbish here. As we have found, Adiga's book is not a novel but a complaint book in epistolary form; critiques of many critics seems compatible with our notion. Shobhan Saxena, in his article "Fact and Fiction" published in Times of India, claims:

...that the west is holding up 'The White Tiger' as a mirror to us. It is telling us that India is not shining and despite its claim of a booming economy, it is still 'the near heart of darkness' which it has been since times immemorial...they (Indian reader) were euphoric when Roy and Kiran Desai won the Booker prize. This time there is a stunned silence: for many of us. Our worst fears have come true- the west is once again using our poverty to humiliate us. (12)

This article, to some extent, dispels our doubts regarding politics in allocation of literary prizes and apart from this, a series of statements endorses our facts recurrently. The novel is an unmediated grievance by an entrepreneur, Balram who turns out to be a 'white tiger' in society. Balram explains his story to a Chinese Premier, Mr Jiaboa- how did he work as a tea maker, what happened during his working period, how did he join as a driver to Mr Ashok and how he became a murderer? In this way, he whimpers about democracy, society, culture, religion, modus vivendi, our political system and so on. And, this is the fulcrum of the whole plot. As the novel proceeds, we find that Balram is very eager not to narrate his own story but to narrate a 'dark picture' of contemporary India. He is enthusiastic to describe the disordered and swarthy picture of India and even in the first letter; he does not miss a chance:

Sir, you Chinese are far ahead of us in every respect, expect that you don't have entrepreneurs and our nation though it has no drinking water, electricity, sewage system, public transportation, sense of hygiene, discipline, courtesy or punctuality... (Adiga 1)

He narrates a past conversation of $\mathrm{Mr}$ Ashok and his wife Pinky where Ashok answers a question of Pinky: "...things have changed so much in India. There are so many more things I could do here than New York now" (Adiga 89). Further, he says, "The way things are changing in India now, this place is going to be like America in ten years" (ibid). But this statement of $\mathrm{Mr}$ Ashok and Balaram presents the contradiction in expression where, on the one hand, India was expected to be America while on the other hand; it was shown to be decaying due to lack of electricity, sense of punctuality and so on. Inappropriate situation and incongruous sentence do not stop here. While describing his father's occupation, Balaram uttered two sentences-firstly, "he is a rickshaw-puller. Sir, he's got no time to name me" (Adigarz) and secondly, "they (the rickshaw-puller) were not allowed to sit on plastic chairs put out for the customers; they had to 
crouch near the back, in that hunched-over, squatting posture common to servants in every part of India" (Adiga24).The excuse of not being named seems to be absurd. Adiga's second statement is a slap on our constitution; reformation and transparent democracy that give equal rights to every citizen. Amitav Kumar, in this regard, suitably says, "I found on nearly every page a witty observation or a fine phrase, and on nearly every page inevitably that sounded false" (1).

Adiga's grumbles culminate when he sees our nation melded in the form of jungle and pungently states that everybody in India lives a life of animal. The essence of the statement is that we are unrestricted. This situation, according to Balram, happened when the British left India. When they used to reign in India, we were in our limitations as we were enslaved and these limitation and boundaries were good for our nation but now, post-independence, we have lost our civilization and we are none other than un-caged animals.

See this country, in its days of greatness, when it was the richest nation was like a zoo.... Then, thanks to all those politicians in Delhi, on fifteenth of August 1947, the day the Britishers left-the cages had been let open; and the animals had attacked and ripped each other apart and jungle law replaced zoo law. (Adiga 63)

Adiga's widespread experience finds Indian education system debased; Indian institutions of marriage demoralized; elections dissipated. It cannot be denied that Adiga is not always mistaken and prejudiced. Although the novel focuses on the 'dark picture' of India, some sort of darkness really lurks in India. He accentuates on criminality in Indian societies and on the entire legal organism corrupted by the department of police: "police searched for me in light; but I hid myself in darkness." The very proclamation is vouched for, as it is not very hard to bribe in order to save the tax what Mr Ashok does in the novel. Adiga's view on the environmental and political pollution-'a fucking joke'-in Delhi cannot be repudiated.

Adiga's explanatory treatment and techniques is undeviating. He does not express people's disillusionment for the corruption. The way Adiga analyses our societal system, it reminds us of the novels of Dickens, Thackeray, Hardy and Lawrence, among others. But they have never given any absurd statement which Adiga has used several times in his novel. On one hand, Eliot's attachment towards oriental religion and philosophy is not concealed. He commends the 'Ganges' in 'The Waste Land' (1922) while on the other, he also discusses disintegration in modern society; disillusionment in post-war generation; and detachment from the religion, etc. But, Adiga mocks the Ganga: "No!- Mr Jiabao, I urge you not to dip in the Ganga, unless you want your mouth full of faces, straw, soggy, parts of human bodies, buffalo..." (20) Additionally, incongruence is observed in his dialogue and situations. To quote Amitav Kumar again, "Halwai's voice sounds like a curious mix of an American teen and a middle-aged Indian essayist. I found Adiga's villains utterly cartoonish, like the characters in a bad Bollywood melodrama." (1)

One of the detriments in Adiga's writing is that he never renders any solution to the problems he raises. His mouthpiece, Balram, only looks intently at the malfeasances that have been conventional in rural region in India. How dexterously he narrates the malefaction, contravention, and transgression in his surroundings but at the same time, he is so butterfingered that he keeps dropping things. His critical thinking about the modern Indian society has a valid reason. To quote Adiga, "I have a real sense of anxiety about this (the modern Indian society). I have old socialist nerves in a capitalist country, and that can make me excessively critical" (quoted in Stephen Moss). If Indian people are living a life of captive, what should be the correct way? If the water of Ganga is dirty, what should be our step to clean it? Shashi Deshpande, in this regard, very aptly remarks: "The writers only job is not to present realities. And what the reader expects, 
however dark the book, is some redeeming quality" (The Hindu 1). Adiga always shrugs off these substantial questions in his novel.

\section{V}

Thus, having discussed the issues and claims made in both the novels at par with the critiques, confabulations, interpretations and avowals given by the critics and writers at unvarying interludes, it will not be inappropriate to clinch that the jury's decision was biased as it acted like "midwife of prizes and prejudice" (Sankarshan Thakur). The contextualization of India by Adiga and its whole-hearted reception in intercontinental literary market ultimately doused the light of Sea of Poppies, which is replete with authentic issues and information, with an epic story of India in the nineteenth century, explores multifarious lives soaked in binaries-of love and sorrow, of respect and disrespect, of frailty and firmness, of fact and fiction, was gnawed by The White Tiger, which ridicules the socio-cultural and politico-economic institutions of India and attempts to escape but not to ameliorate. Sea of Poppies, beautifully textured with dialects, dealing with the nuanced migration of Bhojpuri Girmitiyas, was dwarfed by The White Tiger, which revives and reinscribe a darkly humorous commentary on our system by "foregrounding the material and cultural differences between himself and Westernized diasporic writers" (Mendes 289). Adiga, with his unreasonable and specious words, has not left anything to comment: from materialism to religion, and Ghosh, with his even-handed and accurate observation, has covered everything to reinterpret: from zamidari to indenture.

Ghosh, in order to incorporate varied tastes and cultures, has always made transnationalism a nexus in his fiction. "The basis of Ghosh's transnationalism", writes Bhattacharya, "has been to use fiction the melting pot of the local and the global, the immediate and the universal..." (136). But Ghose's transnationalism, his Dickensian style, excellent narrative technique and unfussiness of language, went unnoticed as the members of the Booker prize committee were busy in admiring Adiga's exoticism as a leading leitmotif. Dwivedi and Lau remind us of the danger of this recurring fallacious illustration of India by Indian diasporic writers. Texts like The White Tiger and God of Small Things are being taught across the globe and we can surmise the situation. Appositely, they state, "[i]t is the diasporic representation of India that is being taught at various universities...while the works of Indian based writers have largely been disregarded and remain unknown and unstudied in postcolonial literature courses" (4).

Summing up, there is no denying fact that literary prizes are political and so are the literary inventions. Sea of Poppies invites the readers for perusal of colonial reality and brings forth the naked legitimacy of the indentured labourers, which is not assimilated by the colonizers. To us, Ghosh's novel, in every sense, is unrivalled and outshines all the novels published in the same year including Adiga's The White Tiger. Irrefutably, Jaya Bhattacharji Rosen is appropriately quoted: "Literary prizes are of many kinds. Some focus on texts, some on authors. Some are meant to encourage young writers, some to recognize achievement." 


\section{Works Cited}

Adiga, Aravind. The White Tiger. UK: Atlantic, 2008. Print.

Barnes, Jonathan. "Prizes are Political: A Conversation about Literary Prize- giving." Review 31. Web. 17 March. 2017. <http://review31.co.uk/essay/view/26/prizes-are-political-a-conversationabout-literary-prizegiving $>$.

Bhattacharya, Sajalkumar. "Amitav Ghosh: The Indian Architect of a Postcolonial Utopia.”

Postliberalization Indian Novels in English. Ed. Aysha Iqbal Viswamohan. London \& New York: Anthem Press, 2013. 127-140. Print.

Bhutto, Fatima. “On Viceroy’s House.”The Guardian, 3 March 2017. Web. 22 May. 2017. $<$ https://www.theguardian.com/film/2017/mar/o3/fatima-bhutto-viceroys-house-watched-servilepantomime-and-wept>.

Das, Gurcharan. Sunday Times of India 19 Oct. 2008. Print.

Derbyshire, Jonathan. “The Politics of Literary Prize-giving.” Financial Times. 4 Nov. 2016.

Web. 19 March. 2017. <https://www.ft.com/content/89f8do56-a109-11e6-86d5-4e36b35c3550>.

Deshpande, Shashi. “Debating Spaces."Hindu 1 February 2009. Print.

Dhillon, Amrit. "Indians fear Aravind Adiga's 'The White Tiger' says too much about them."

The Telegraph18 Oct. 2008. Web. 26 May. 2017.

$<$ http://www.telegraph.co.uk/news/worldnews/asia/india/3222136/Indians-fear-Aravind-AdigasThe-White-Tiger-says-too-much-about-them.html>.

Dwivedi, Om Prakash, and Lisa Lau, eds. Indian Writing in English and Global Literary Market. London: Palgrave MacMillan, 2014.1-9. Print.

Ghosh, Amitav. Sea of Poppies. New Delhi: Harper Collins, 2008. Print.

---. Interview. Confronting the Past. By Priyamvada Gopal. Hindu Literary Review 1 June 2008. Weekly Edition 3. Print.

Higgins, Charlotte. “Out of the Darkness: Adiga’s White Tiger Rides to Booker Victory against the odds." The Guardian, 14 Oct. 2008. Web. 6 May. 2017. $<$ https://www.theguardian.com/books/2008/oct/14/booker-prize-adiga-white-tiger>.

Jenkins, Simon. “Novels Tells Exotic Tales from India”. Times of India 19 Oct. 2008. Print.

Kumar, Amitav. "On Adiga’s The White Tiger." Hindu Book Review 2 Nov. 2008. Print.

Lau, Lisa. "Re-Orientalism in Contemporary Indian Writing in English." Re-Orientalism and

South Asian Identity Politics: The Oriental Other Within. Eds. Lisa Lau and Ana Mendes. London \& New York: Routledge, 2011. 17-41. Print.

Mahanta, Arpana. "Allegories of the Indian Experiences: The Novels of Salman Rushdie."

Economic and Political Weekly 19.6 (1984): 244-247. Print.

Mendes, Ana. "Exciting Tales of Exotic Dark India: Aravind Adiga's The White Tiger."

Web. 10 July. 2017. <http://www.academia.edu/3273067/Exciting Tales of Exotic Dark India Aravind Adiga s The White Tiger $>$ 
Moss, Stephen. “Aravind Adiga: 'I was afraid the White Tiger would eat me up too.”Web.

25 Aug. 2017. <https://www.theguardian.com/books/2017/aug/25/aravind-adiga-books-interviewselection-day-the-white-tiger?CMP=share btn $\mathrm{fb}>$

Nayar, Pramod K. "Indian Writing in English as Celebrity." Indian Writing in English and

Global Literary Market. Eds. O P Dwivedi \& Lisa Lau. London: Palgrave MacMillan, 2014.32-47. Print.

Rosen, Jaya Bhattacharji. “The Prize is Right?” Web. 6 Aug. 2017.

$<$ http://www.thehindu.com/books/literary-review/authors-publishers-and-members-of-awardjuries-discuss-if-indian-literary-prizes-set-literary-standards/article6842116.ece>.

Saxena, Shobhan. "Fact and Fiction.”Times of India 19 Oct. 2008. Print.

Thakur, Sankarshan. “The hero India doesn't want.” Telegraph. 16 Nov. 2008. Web.

12 Aug. 2017. <https://www.telegraphindia.com/1081116/jsp/7days/story 10117416.jsp>

\section{Bio-note of the authors:}

Satyanarayan Tiwari, UGC-NET (JRF), is a doctoral candidate at the Department of English, Dr. H S Gour Central University, Sagar. Prior to this, he has obtained his Masters in English Literature from Banaras Hindu University, Varanasi (UP) India.

Dr. Ajay $\mathbf{K}$ Chaubey is Assistant Professor of English at the Department of Sciences \& Humanities, National Institute of Technology, Uttarakhand. His major academic publications include V S Naipaul (Atlantic, 2015), Salman Rushdie (Atlantic, 2016) followed by South Asian Diasporic Cinema and Theatre (Rawat, 2017). Dr. Chaubey loves to explore the unexplored and nuanced territory of travel narratives on South Asia while he craves for unfolding the cultural history of his own place, bāgi Ballia, where he belongs to. 